\title{
Troglitazone induces apoptosis in gastric cancer cells through the NAG-1 pathway
}

\author{
CHUNHUI WANG, JING WANG and PING BAI \\ Department of Gastroenterology, West China Hospital, Sichuan University, Chengdu 61004, P.R. China
}

Received June 15, 2010; Accepted September 23, 2010

DOI: $10.3892 / \mathrm{mmr} .2010 .381$

\begin{abstract}
The non-steroidal anti-inflammatory drug-activated gene (NAG-1) is a newly identified member of the transforming growth factor (TGF)- $\beta$ superfamily and plays significant roles in regulating proliferation and pro-apoptotic activities. In the present study, we studied the regulation of NAG-1 by troglitazone in the cultured gastric cancer cell line BGC-823. MTT and TUNEL assays demonstrated that troglitazone potentially inhibits the proliferation of the gastric cancer cell line and induces apoptosis in vitro in a dose- and time-dependent manner. Troglitazone induced concentration-dependent NAG-1 expression in the BGC-823 cells, as assessed using immunocytochemistry. Furthermore, troglitazone increased Egr-1 protein levels in a concentration-dependent manner. In conclusion, the present study suggests that troglitazone markedly impedes proliferation and pro-apoptotic activities in BGC- 823 cells, and the mechanism may partly be through the Egr-1 pathway.
\end{abstract}

\section{Introduction}

Gastric cancer is one of the most common types of malignancies. It is very difficult to diagnose at earlier stages, and usually no potentially curative therapy is possible at advanced stages. The use of chemotherapy drugs is limited due to serious side effects and intolerance. Therefore, novel therapeutic approaches for the treatment of gastric cancer require immediate investigation.

Troglitazone (TGZ), a thiazolidinedione derivative, is a ligand for PPAR $\gamma$ that binds and activates PPAR $\gamma$ and has wide biological activities (1). Apart from enhancing insulin sensitivity, anti-atherogenesis and anti-inflammation, TGZ has been reported to have a potent anti-tumor effect (2-4). Recent studies have confirmed that thiazolidinediones may inhibit

Correspondence to: Professor Chunhui Wang, Department of Gastroenterology, West China Hospital, Sichuan University, Guo Xue Xiang 37, Chengdu 610041, P.R. China

E-mail: wangch@scu.edu.cn

Key words: troglitazone, non-steroidal anti-inflammatory drugactivated gene, Egr-1, gastric cancer the growth of cancer cells dependently and independently of the PPAR $\gamma$ pathway in vitro. Furthermore, its independence of the PPAR $\gamma$ pathway continues to be an important issue. The up-regulation of NAG-1 by the thiazolidine derivative MCC-555 in a PPAR $\gamma$-independent manner has been confirmed to promote apoptosis in human colorectal cancer cells (5). However, it is largely unknown whether TGZ induces NAG-1 expression to inhibit growth and induce apoptosis in human gastric cancer cells. In the present study, we examined whether NAG-1 expression is induced in gastric cancer cells by TGZ, and the effect of NAG-1 expression on cancer cell biological behavior.

\section{Materials and methods}

Cell cultures. The human gastric cancer cell line BGC-823 (provided by Biotherapy State Key Laboratory, China) was cultured and maintained in RPMI-1640 (Invitrogen, Carlsbad, CA, USA) supplemented with $10 \%$ fetal bovine serum (Invitrogen), $2 \mathrm{mM}$ glutamine, $100 \mathrm{U}$ penicillin $/ \mathrm{ml}$, and $100 \mu \mathrm{g}$ of streptomycin $/ \mathrm{ml}$, and incubated at $37^{\circ} \mathrm{C}$ in $5 \%$ $\mathrm{CO}_{2}$.

Cell viability assay. Cell viability was determined by the MTT [3-(4,5-dimethylthiazole)-2,5-diphenyltetrazolium bromide] assay. Briefly, $5 \times 10^{3}$ cells/well were seeded in 96-well plates and allowed to attach overnight. The concentrations of TGZ (Sigma, St. Louis, MO, USA) were 0.5, 1, 5, 15, 25 and $50 \mu \mathrm{mol} / 1$, respectively. Each group contained three wells. After the samples were treated with TGZ for 24 or $48 \mathrm{~h}, 20 \mu \mathrm{l}$ of MTT $(0.5 \mathrm{mg} / \mathrm{ml}$; Sigma) was added to each well, and the cells were incubated at $37^{\circ} \mathrm{C}$ for $4 \mathrm{~h}$. The reaction was then halted by lysing the cells with $200 \mu$ l of dimethyl sulfoxide (DMSO) for $15 \mathrm{~min}$. Quantification measurements (optical density) were obtained at a wavelength of $570 \mathrm{~nm}$ using spectrophotometric analysis.

TUNEL assay for detection of apoptosis. To investigate the apoptosis in gastric carcinoma cells induced by TGZ, the TdT-mediated dUTP nick-end labeling (TUNEL) assay was carried out using an apoptosis detection system (Roche Diagnostics, Indianapolis, IN, USA). Cell culture and treatment were carried out as described above. For quantitative evaluation of apoptotic cells, 10 fields (at least 200 cells) were counted in each preparation. The apoptotic rate was 
calculated as the number of apoptotic cells/number of total cells x $100 \%$.

Measurement of apoptosis by flow cytometry. BGC-823 cells were plated at a density of $4 \times 10^{5}$ cells/well in 6-well plates, incubated for $24 \mathrm{~h}$, and then treated with different concentrations of TGZ for $48 \mathrm{~h}$. Thereafter, the cells were harvested, washed with phosphate-buffered saline (PBS) and stained using the Annexin V-FITC reagent kit (Promega, Madison, WI, USA) according to the manufacturer's instructions. Briefly, the cells were stained with $5 \mu \mathrm{l}$ Annexin V-FITC and $5 \mu \mathrm{l}$ propidium iodide (PI) in $500 \mu \mathrm{l}$ binding buffer in the dark at room temperature for $15 \mathrm{~min}$, respectively. They were then examined by FACScan (BD Biosciences), and data were processed using Cell Quest ${ }^{\mathrm{TM}}$ software (BD Biosciences).

Immunocytochemistry of NAG-1. BGC-823 cells were plated in 24-well plates containing pre-coated slides at a density of $5 \times 10^{4}$ cells/well, incubated for $16 \mathrm{~h}$ and then treated with the indicated concentrations of TGZ containing $1 \%$ serum for the indicated times. After treatment, the cell samples were washed with PBS, fixed, air dried with $4 \%$ paraformaldehyde for $30 \mathrm{~min}$, and then incubated in $0.1 \%$ Triton X-100 for $10 \mathrm{~min}$ on ice, in $3 \% \mathrm{H}_{2} \mathrm{O}_{2}$ in the dark for $10 \mathrm{~min}$ and in normal goat serum for $15 \mathrm{~min}$. Subsequently, the samples were incubated with anti-NAG-1 antibody (Upstate Biotechnology, NY, USA) at $4^{\circ} \mathrm{C}$ overnight. After washing with PBS, they were treated with biotinylation secondary antibody and horseradish peroxidase-conjugated streptavidin for $15 \mathrm{~min}$, respectively. The samples were added to the DAB substrate for incubation for 2-5 min, and analysis by light microscopy was carried out after counterstaining. Yellow cytoplasm indicated NAG-1positive expression. The percentage of positive gastric cancer cells was calculated after each slide was observed in 10 highpower fields.

Western blot analysis for Egr-1. BGC-823 subline cells (1x10 cells/well) were incubated with 5,15 and $25 \mu \mathrm{mol} / 1$ TGZ and serum-free RPMI-1640 separately for $3 \mathrm{~h}$ at $37^{\circ} \mathrm{C}$ in a humidified $5 \% \mathrm{CO}_{2}$ atmosphere. The concentrations of protein extracted from the $\mathrm{BGC}-823$ cells were determined by Lowry method. Protein $(20 \mu \mathrm{g} / \mathrm{well})$ was loaded onto $8 \%$ SDS-PAGE gels and separated by electrophoresis. The proteins were then transferred onto PVDF membranes (Roche Diagnostics, Indianapolis, IN, USA), and each blot was immunolabeled with rabbit polyclonal antibody for Egr-1 (Santa Cruz Biotechnology Inc., Santa Cruz, CA, USA) at $4^{\circ} \mathrm{C}$ overnight. Membranes were incubated with horseradish peroxidase-linked immunoglobulin and exposed to enhanced chemiluminescence Western blotting luminal reagent (Santa Cruz Biotechnology, Inc.) followed by autoradiography. Western blotting was performed at least 3 times to ensure reproducibility. To correct for variations in loading, the blots were stripped and incubated with a monoclonal anti-actin antibody (1:3000; Santa Cruz Biotechnology, Inc.). The optical density (OD) of the protein band was analyzed by Band Scan Figure software (Glyko, Novato, CA, USA), and the ratio of the OD for Egr-1 to the OD for actin was calculated.

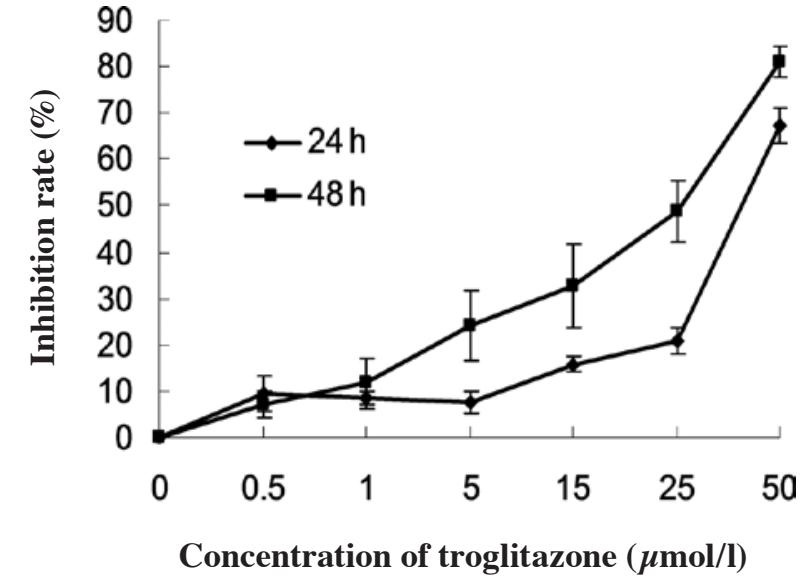

Figure 1. Anti-proliferative effects of troglitazone (TGZ) on BGC-823 cells. Cells were plated at a density of $5 \times 10^{3}$ cells per well ( 6 replicates/group) in 96-well plates and exposed to TGZ treatment for 24 or $48 \mathrm{~h}$. The viable cell number was determined by MTT colorimetric assay and indicated as a percentage of the control. The results represent the average of three independent experiments.

Statistical analysis. Statistical significance was determined for P-values $<0.05$ by one-way ANOVA.

\section{Results}

Troglitazone inhibits BGC-823 cell growth. After treatment with TGZ at concentrations ranging from 0.5 to $50 \mu \mathrm{mol} / \mathrm{l}$ for 24 and $48 \mathrm{~h}$, the viability of the cells was significantly lower than that of the untreated corresponding control groups $(\mathrm{P}<0.05)$. Ratios of cell proliferation inhibition in the BGC-823 cells were linearly positive and dose-dependent (Fig. 1). TGZ inhibited the proliferation of the gastric cancer cell line in vitro in a dose- and time-dependent manner.

Induction of apoptosis by troglitazone. After $48 \mathrm{~h}$ of incubation, TUNEL staining of the BGC-823 cells showed more scattered apoptotic cells with brown nucleoli in the TGZ-treated groups than in the control (Fig. 2). Flow cytometric analyses of the binding of fluorescence-labeled Annexin $\mathrm{V}$ to externalized phosphatidylserine was also performed in order to quantify early apoptotic cells. PI uptake was measured to assess cells in the late stages of apoptosis or cells that sustained direct plasma membrane damage. Fig. 3 shows flow cytometric plots obtained with the Annexin V-PI assay after a 48 -h exposure to different concentrations ( 0.5 to $50 \mu \mathrm{mol} / \mathrm{l})$ of TGZ. The number of early and late apoptotic cells or directly damaged cells increased after exposure of the cells to TGZ.

NAG-1 involvement in troglitazone-induced apoptosis. Immunocytochemical staining revealed that NAG-1 expression was negative in the BGC-823 cells. After treatment with different concentrations of TGZ ( 0.5 to $25 \mu \mathrm{mol} / \mathrm{l})$ for $48 \mathrm{~h}$, NAG-1 expression was induced in a concentration-dependent manner. The positive rates of NAG-1 were $13.3 \pm 4.04$, $30.7 \pm 5.51,50.3 \pm 5.8675 .3 \pm 5.51$ and $91.3 \pm 3.06 \%$, separately (Fig. 4). 

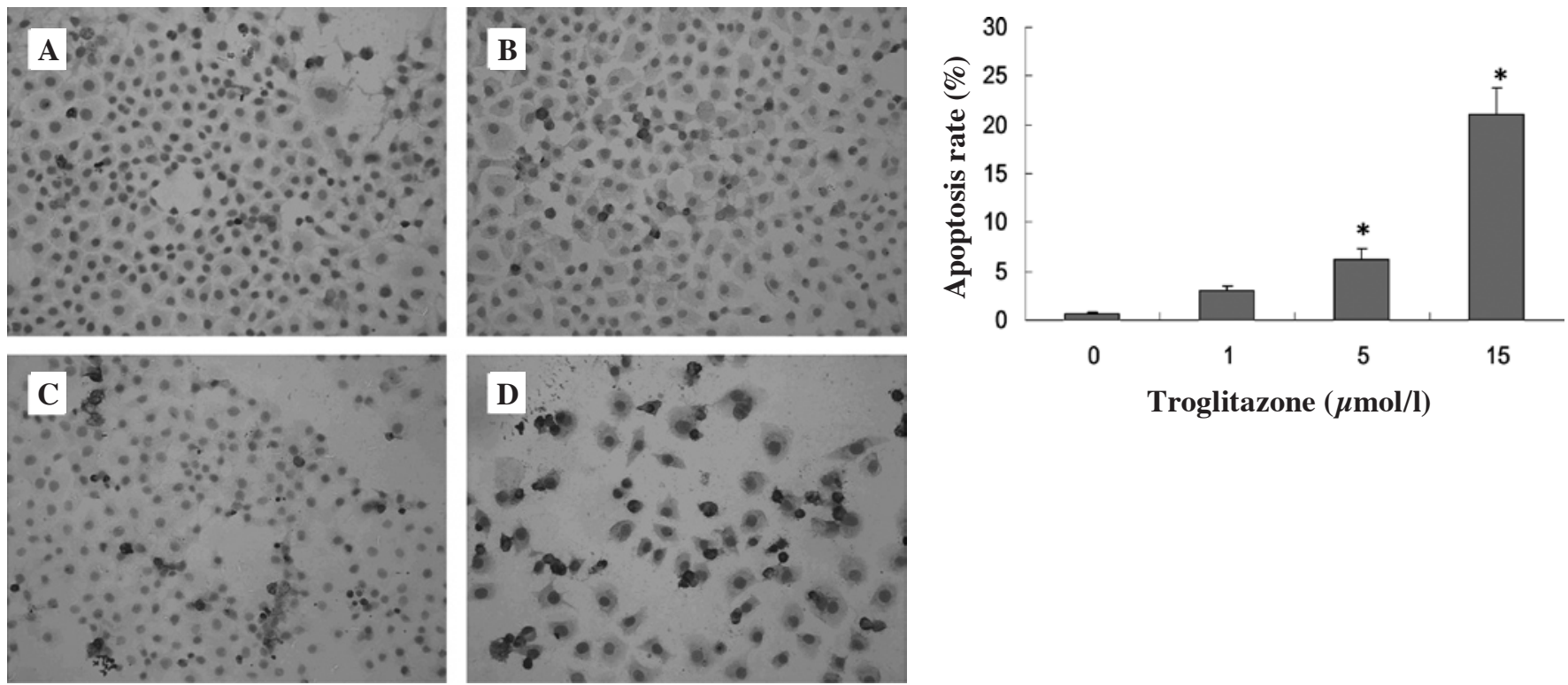

Troglitazone $(\mu \mathrm{mol} / \mathrm{l})$

Figure 2. TUNEL staining of apoptotic BGC-823 cells (48 h). Cell apoptosis was assessed by TUNEL assay which showed a markedly greater percentage of TUNEL-positive nuclei in the TGZ groups vs. the control group. (A) Control group. Cells treated with (B) 1, (C) 5 and (D) $15 \mu \mathrm{mol} / 1$ of TGZ, respectively. ${ }^{*} \mathrm{P}<0.05$, control group compared with the TGZ groups.
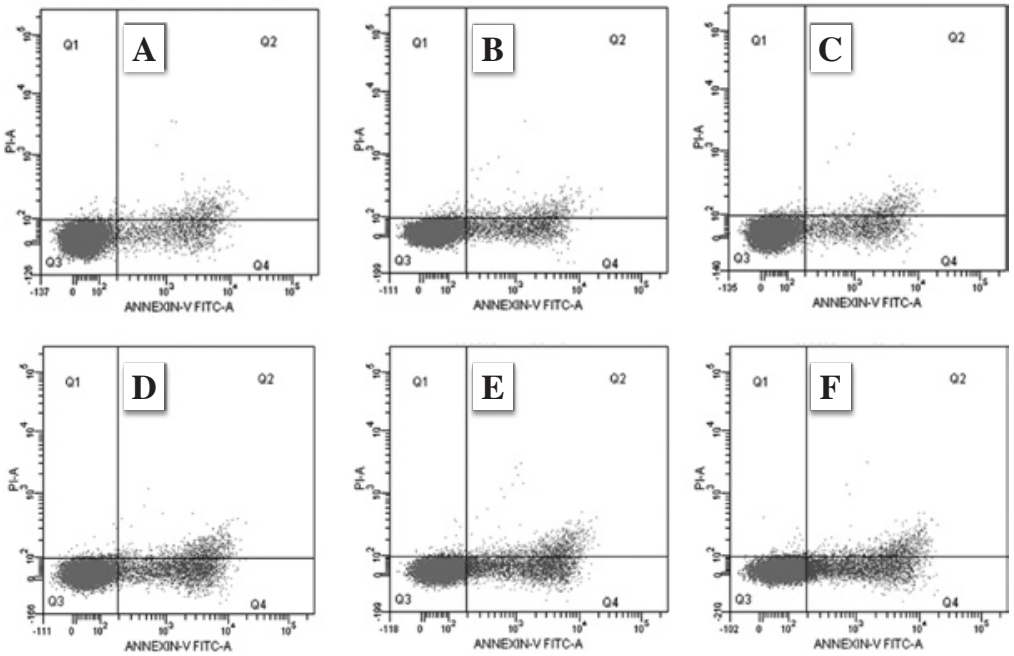

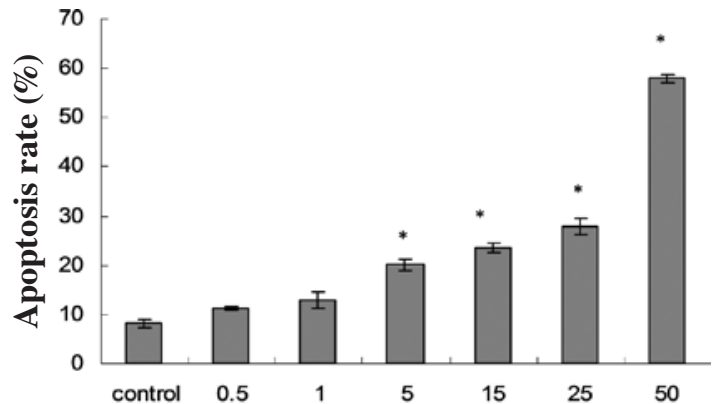

Concentration of troglitazone $(\mu \mathrm{mol} / \mathrm{l})$

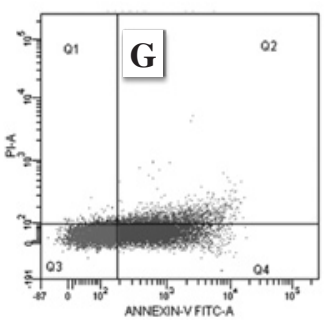

Figure 3. Effect of troglitazone (TGZ) on the apoptosis rate of BGC-823 cells. The rate of apoptosis was detected with FCM using Annexin V-FITC/PI double staining. Stained cell populations were defined as follows: Q2, late apoptotic or necrotic cells (Annexin $\mathrm{V}^{+}, \mathrm{PI}^{+}$); Q3, viable or undamaged cells (Annexin $\mathrm{V}^{-}, \mathrm{PI}$ ); and $\mathrm{Q} 4$, cells undergoing early apoptosis (Annexin $\left.\mathrm{V}^{+}, \mathrm{PI}\right)$. BGC-823 cells were treated with various concentrations of TGZ for $48 \mathrm{~h}$. (A) Control group. Cells treated with (B) 0.5 , (C) 1 , (D) 5 , (E) 15 , (F) 25 and (G) $50 \mu \mathrm{mol} / 1$ of TGZ, respectively. An increase in apoptosis was noted at $5 \mu \mathrm{mol} / 1$ TGZ and this increase was in a dose-dependent manner. The figures are representative of three separate experiments. "P<0.05, control group compared to the TGZ groups.

Induction of Egr-1 by troglitazone. The protein level of Egr-1 in the BGC-823 cells was measured by Western blotting. As expected, the level of Egr-1 increased in response to different concentrations of TGZ (Fig. 5). These results suggest that TGZ induces Egr-1 protein expression in BGC-823 cells. 

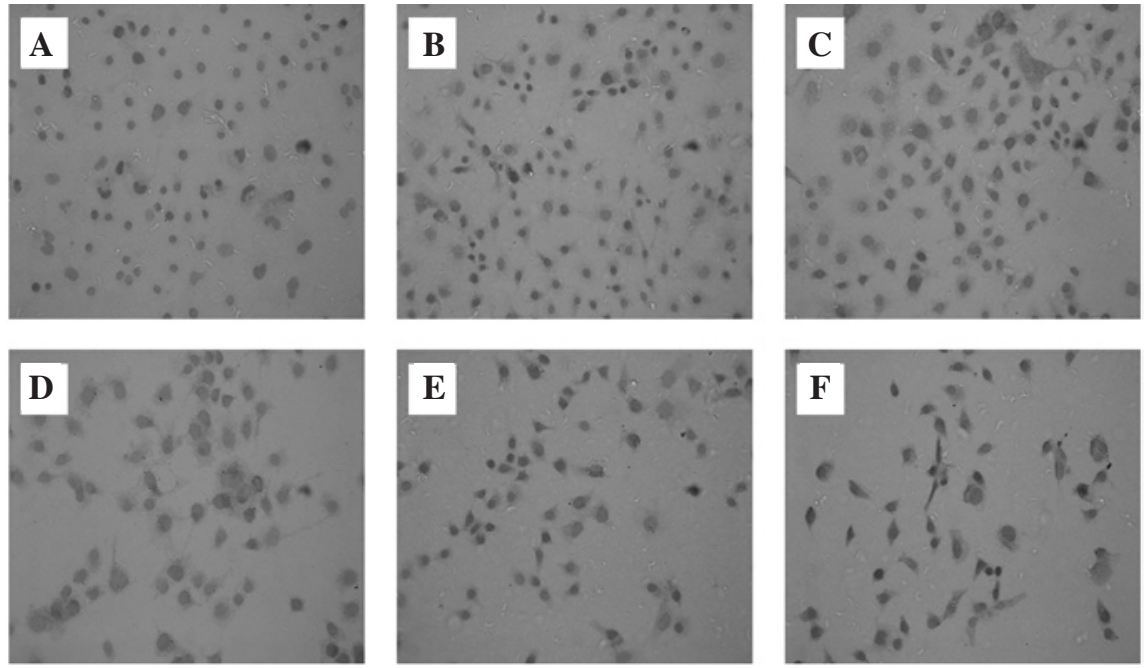

Figure 4. Immunocytochemical staining for NAG-1 in the BGC-823 cells. (A) NAG-1 was negatively expressed in the control groups. Expression of NAG-1 after treatment with (B) 0.5, (C) 1, (D) 5, (E) 15, and (F) $25 \mu \mathrm{mol} / 1$ of TGZ; NAG-1 expression was induced in the cytoplasm in a concentration-dependent manner.

A

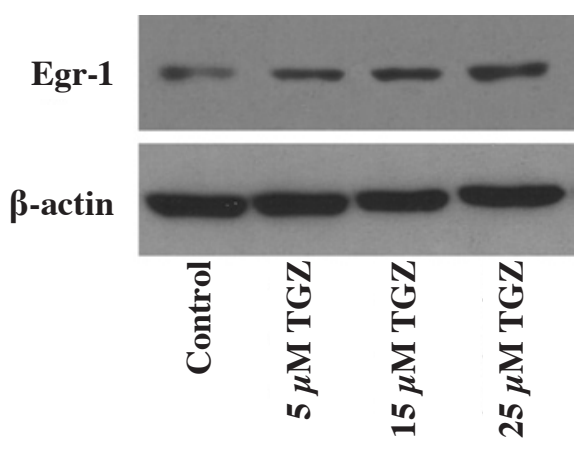

B

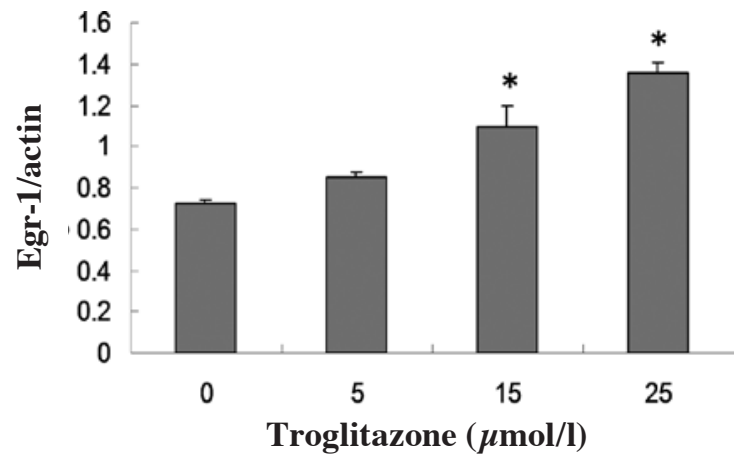

Figure 5. Induction of Egr-1 expression by TGZ in BGC-823 cells. Protein (30 $\mu \mathrm{g})$ was loaded on SDS-PAGE gels, and immunoblotting was performed. Rabbit Egr-1 polyclonal antibody and $\beta$-actin antibody were used to detect Egr-1 and $\beta$-actin, respectively. Expression of Egr-1 protein was calculated by the density of the Egr-1 band over that of the $\beta$-actin band. Results represent the average of three independent experiments, and data are shown as the mean \pm SD. ${ }^{*} \mathrm{P}<0.05$, control group compared to the TGZ groups.

\section{Discussion}

Troglitazone is a PPAR $\gamma$ ligand and may be regarded as a novel and promising agent in cancer therapy as it can facilitate differentiation, inhibit growth, induce apoptosis, and inhibit the angiopoiesis, migration and invasion of tumor cells (6-9). Although the anti-tumorigenic activities of PPAR $\gamma$ ligands are well-established in human cancer, controversy exists in the literature with regard to the relative contributions of nuclear receptor-dependent and -independent mechanisms (10). A recent study confirmed that a novel peroxisome proliferatoractivated receptor gamma ligand, MCC-555, induces apoptosis via post transcriptional regulation of NAG-1 in colorectal cancer cells in a PPAR $\gamma$-independent manner (5).

NAG-1 (also known as MIC-1, GDF-15, PLAB and placental TGF- $\beta$ ), a member of the TGF- $\beta$ superfamily, is involved in tumor progression and development (11-14). The overexpression of NAG-1 in cancer cells results in growth arrest and an increase in apoptosis, and suggests that NAG-1 has anti-tumorigenic and pro-apoptotic activity $(15,16)$. In our provious study, we found that NSAIDs induced NAG-1 in SW480, LS174T and SW480 colon cancer cells (17). In the present study, we demonstrated that the BGC-823 human gastric cancer cell line did not express NAG-1, while TGZ induced the expression of NAG-1 protein. NAG-1 protein was located in the cytoplasm and the positive rates of NAG-1 were gradually increased at TGZ concentrations ranging from 0.5 to $25 \mu \mathrm{mol} / 1$ at $48 \mathrm{~h}$. This result illustrates that, apart from NSAIDs, TGZ may also induce the expression of NAG-1 in a dose-dependent manner.

To confirm the relationship between NAG-1 induction and biological activities in BGC-823 cells treated with TGZ, we investigated the inhibition of cell proliferation and the induction of apoptosis by TGZ at concentrations ranging from 0.5 to $50 \mu \mathrm{mol} / \mathrm{l}$. The percentages of inhibition of cell proliferation were gradually increased at TGZ concentrations ranging from 0.5 to $50 \mu \mathrm{mol} / \mathrm{l}$ at $24 \mathrm{~h}$, and were respectively up-regulated at $48 \mathrm{~h}$. The result is compatible with those obtained in cholangiocarcinoma cells (18). Moreover, apoptosis was induced by TGZ in a dose-dependent manner. In an effort to better understand the mechanisms responsible for these cellular responses, we measured the expression of Egr-1 protein and found that TGZ stimulates the expression of Egr-1 in a concentrationdependent manner. Egr-1 is a member of the immediate early 
gene response family and encodes a nuclear phosphoprotein involved in the regulation of cell growth and differentiation in response to signals such as mitogens, growth factors and stress stimuli (19-21). However, evidence suggests that Egr-1 binding sites are located within region -73 to -51 of the NAG-1 promoter, and the overexpression of Egr-1 results in increased NGA-1 expression. We confirmed that TGZ induced expression of NAG-1 in BGC-823 gastric cancer cells and induced apoptosis partly through the Egr-1 pathway.

In conclusion, the PPAR $\gamma$ ligand TGZ may induce NAG-1 expression in gastric cancer cells and is closely related to reduced cell viability and increased apoptosis. The mechanisms of this action may be related to stimulation of the expression of the transcription factor Egr-1, a protein with established tumor suppressor activity.

\section{References}

1. Lehmann JM, Moore LB, Smith-Oliver TA, Wilkison WO, Willson TM and Kliewer SA: An antidiabetic thiazolidinedione is a high affinity ligand for peroxisome proliferator-activated receptor gamma (PPAR $\gamma)$. J Biol Chem 270: 12953-12956, 1995.

2. Wijk JP and Rabelink TJ: Impact of thiazolidinedione therapy on atherogenesis. Curr Atheroscler Rep 7: 369-374, 2005.

3. Sung B, Park S, Yu BP and Chung HY: Amelioration of agerelated inflammation and oxidative stress by PPARgamma activator: suppression of NF-kappaB by 2,4-thiazolidinedione. Exp Gerontol 41: 590-599, 2006.

4. Weng JR, Chen CY, Pinzone JJ, Ringel MD and Chen CS: Beyond peroxisome proliferator-activated receptor gamma signaling: the multi-facets of the antitumor effect of thiazolidinediones. Endocr Relat Cancer 13: 401-413, 2006.

5. Yamaguchi K, Lee SH, Eling TE and Baek SJ: A novel peroxisome proliferator-activated receptor gamma ligand, MCC-555, induces apoptosis via posttranscriptional regulation of NAG-1 in colorectal cancer cells. Mol Cancer Ther 5: 1352-1361, 2006.

6. Demetri GD, Fletcher CD, Mueller E, Sarraf P, Naujoks R, Campbell N, Spiegelman BM and Singer S: Induction of solid tumor differentiation by the peroxisome proliferator-activated receptor-gamma ligand troglitazone in patients with liposarcoma. Proc Natl Acad Sci USA 96: 3951-3956, 1999.

7. Takahashi N, Okumura T, Motomura W, Fujimoto Y, Kawabata I and Kohgo Y: Activation of PPARgamma inhibits cell growth and induces apoptosis in human gastric cancer cells. FEBS Lett 455: 135-139, 1999.

8. Huang H, Campbell SC, Bedford DF, Nelius T, Veliceasa D, Shroff EH, Henkin J, Schneider A, Bouck N and Volpert OV: Peroxisome proliferator-activated receptor gamma ligands improve the antitumor efficacy of thrombospondin peptide ABT510. Mol Cancer Res 2: 541-550, 2004.
9. Coras R, Hölsken A, Seufert S, Hauke J, Eyüpoglu IY, Reichel M Tränkle C, Siebzehnrübl FA, Buslei R, Blümcke I and Hahnen E: The peroxisome proliferator-activated receptor-gamma agonist troglitazone inhibits transforming growth factor-beta-mediated glioma cell migration and brain invasion. Mol Cancer Ther 6: 1745-1754, 2007.

10. Rumi MA, Ishihara S, Kadowaki Y, Ortega-Cava CF, Kazumori H, Kawashima K, Yoshino N, Yuki T, Ishimura N and Kinoshita Y: Peroxisome proliferator-activated receptor gammadependent and -independent growth inhibition of gastrointestinal tumour cells. Genes Cells 9: 1113-1123, 2004.

11. Eling TE, Baek SJ, Shim M and Lee CH: NSAID activated gene (NAG-1), a modulator of tumorigenesis. J Biochem Mol Biol 39: 649-655, 2006

12. Kim JS, Baek SJ, Sali T and Eling TE: The conventional nonsteroidal anti-inflammatory drug sulindac sulfide arrests ovarian cancer cell growth via the expression of NAG-1/MIC-1/ GDF-15. Mol Cancer Ther 4: 487-493 2005.

13. Baek SJ, Okazaki R, Lee SH, Martinez J, Kim JS, Yamaguchi K, Mishina Y, Martin DW, Shoieb A, McEntee MF, Eling TE: Nonsteroidal anti-inflammatory drug-activated gene-1 over expression in transgenic mice suppresses intestinal neoplasia. Gastroenterology 131: 1553-1560, 2006.

14. Lee SH, Krisanapun C and Baek SJ: NSAID-activated gene-1 as a molecular target for capsaicin-induced apoptosis through a novel molecular mechanism involving GSK3beta, C/EBPbeta and ATF3. Carcinogenesis 31: 719-728, 2010.

15. Baek SJ, Kim KS, Nixon JB, Wilson LC and Eling TE: Cyclooxygenase inhibitors regulate the expression of a TGF-beta superfamily member that has proapoptoic and antitumorigenic activities. Mol Pharmacol 59: 901-908, 2001.

16. Jang TJ, Kang HJ, Kim JR and Yang CH: Non-steroidal antiinflammatory drug activated gene (NAG-1) expression is closely related to death receptor- 4 and -5 induction, which may explain sulindac sulfide-induced gastric cancer cell apoptosis. Carcinogenesis 25: 1853-1858, 2004.

17. Wang C, Ouyang Q, Tang C, Liu R and Huang M: Induction of NAG-1 gene expression in colon cancer cells by non-steroidal anti-inflammatory drugs. Sheng Wu Yi Xue Gong Cheng Xue Za Zhi 24: 880-883, 2007.

18. Kobuke T, Tazuma S, Hyogo H and Chayama K: A ligand for peroxisome proliferator-activated receptor gamma inhibits human cholangiocarcinoma cell growth: potential molecular targeting strategy for cholangioma. Dig Dis Sci 51: 1650-1657, 2006.

19. Baek SJ, Kim JS, Nixon JB, DiAugustine RP and Eling TE: Expression of NAG-1, a transforming growth factor-beta superfamily member, by troglitazone requires the early growth response gene EGR-1. J Biol Chem 279: 6883-6892, 2004.

20. Shimoyamada H, Yazawa T, Sato H, Okudela K, Ishii J, Sakaeda M, Kashiwagi K, Suzuki T, Mitsui H, Woo T, Tajiri M, Ohmori T, Ogura T, Masuda M, Oshiro H and Kitamura H.:Early growth response-1 induces and enhances vascular endothelial growth factor-a expression in lung cancer cells. Am J Pathol 177: 70-83, 2010.

21. Parra E and Ferreira J: The effect of siRNA-Egr-1 and camptothecin on growth and chemosensitivity of breast cancer cell lines. Oncol Rep 23: 1159-1165, 2010. 